\title{
The feasibility of the north-eastern USA supporting the return of the cougar Puma concolor
}

JOHN W. LAUNDRÉ

\begin{abstract}
The cougar Puma concolor was part of the preEuropean fauna of the north-eastern USA. It was extirpated in the late 1800 s and since the late 1900 s there have been discussions concerning its reintroduction to the region. One site considered is Adirondack State Park in northern New York. In 1981 an assessment of the feasibility of returning cougars concluded that the Park had adequate prey and forest cover to support a small population of cougars but that conflicts with humans would cause the demise of this population within 10 years. Thus reintroduction at that time was not advised. Since then knowledge of cougar ecology and how cougars interact with humans has increased substantially. Based on information compiled since the 1980 I conducted a landscape-scale analysis to assess whether cougars could live in the Park. The results indicate that cougars could occupy $15,300-17,000 \mathrm{~km}^{2}$ (61$69 \%)$ of the Park, with minimal contact with human habitation. Based on reported cougar densities the Park could support a population of $150-350$ cougars. These cougars would consume $<10 \%$ of the adult deer population annually and fawn production would be sufficient to replace these losses. Human and road densities in the Park are similar to those of the Black Hills, South Dakota and southern Florida, both of which have viable populations of cougars. I concluded that Adirondack State Park could support a population of cougars. What is now required is the will to bring them back.
\end{abstract}

Keywords Adirondack State Park, cougar, feasibility, north-eastern USA, Puma concolor, reintroduction

\section{Introduction}

T arge mammalian carnivores experienced significant $\triangle$ range reductions worldwide in the second half of the 2oth century (Gittleman \& Gompper, 2001; Pyare et al., 2004; Treves, 2009). In efforts to reverse these trends a common tool is the reintroduction of species into their former range (Gittleman \& Gompper, 2001). The debate regarding any reintroduction effort usually centres on two main concerns: (1) is there sufficient habitat/food to support the introduced species, and (2) is the public's attitude

JOHN W. LAUNDRÉ Department of Biological Sciences, 316 Syngg Hall, SUNY Oswego, Oswego, New York, USA. E-mail john.laundre@oswego.edu

Received 4 July 2011. Revision requested 28 July 2011.

Accepted 23 August 2011. favourable towards the species' return (Nilsen et al., 2007)? Although public acceptance of a carnivore's return is important to the success of a reintroduction effort, assessing the adequacy of an area to support the species is the first step. Without sufficient habitat and food resources even the most publicly supported reintroduction effort will fail.

An assessment of the habitat and food resources of an area for the reintroduction of a large carnivore requires a landscape-scale analysis of its habitat, information on how the species will use the landscape, details of its food requirements and an assessment of prey resources. One such species for which this detailed analysis is needed is the American cougar Puma concolor. Over its current range in western North and South America the cougar is categorized as Least Concern on the IUCN Red List (Caso et al., 2008). However, the eastern subspecies $P$. concolor cougar, which was part of the pre-European fauna of the north-eastern USA, was extirpated from the region in the late $1800 \mathrm{~s}$ (Young \& Goldman, 1946). Until 2011 this subspecies was listed as endangered under the Endangered Species Act but has recently been listed as extinct by the US Fish and Wildlife Service. There have been discussions concerning the possible reintroduction of $P$. concolor into the region from western populations but one of the main arguments against this is that there is inadequate habitat in the densely human-populated eastern forest to support cougars (Brocke, 1981). However, there are several large $(>3,000$ $\mathrm{km}^{2}$ ) relatively undisturbed areas in the north-eastern landscape. Much of the debate concerning the reintroduction of $P$. concolor centres on whether these and similar areas are large enough and wild enough to support viable populations of the species. One area being considered is Adirondack State Park in northern New York. Because of its vast size $\left(>24,000 \mathrm{~km}^{2}\right)$ and relatively pristine state $(>45 \%$ is publicly owned land classified as wilderness/wild forest), this Park is a potential relocation site. If cougars could survive in the Park their return to other areas in the region could also be feasible.

In the 1980s Brocke (1981) evaluated Adirondack State Park with regard to its potential to maintain cougars. He identified a hypothetically suitable area of $7,500 \mathrm{~km}^{2}$ within the Park that contained low road and human densities. Brocke estimated that this area could support a population of c. 116 cougars ( 1.5 cougars per $100 \mathrm{~km}^{2}$ ). However, because of the high human and road densities in the Park compared to then existing studies in the western USA (Hornocker, 1970; Seidensticker et al., 1973; Lindzey et al., 1988) Brocke (1981) concluded that human-induced mortality would 
cause a population of 100 cougars to become extinct within 10 years. His recommendation (Brocke, 1981) was that 'Reintroduction of cougars in Adirondack State Park is currently not advisable in light of the data presented in this report'. This recommendation was probably influenced by the fact that, until the early 1970s, cougars were hunted without control (Dawn, 2002). Today, however, cougars are game species in most western states and there is strict control over the number of animals killed (Dawn, 2002). Nevertheless, Brocke's report is still cited as one of the reasons that reintroduction of cougars into the Park, and the north-east in general, is unjustified (Bolgiano \& Roberts, 2005). Although Brocke's work was based on the knowledge available about cougars at the time, the research of Hornocker (1970) and Seidensticker et al. (1973) was not taken into account and research in southern Utah by Lindzey et al. (1988) would not be published for another few years. Since that time our knowledge and understanding of cougar behaviour and ecology has greatly expanded (Hornocker \& Negri, 2010).

The aim of this research is therefore to reanalyse the suitability of Adirondack State Park to support cougars. My objectives are to: (1) determine the validity of Brocke's assumptions, primarily by examining the literature that has been published since 1981, (2) conduct a landscape-level analysis of the habitat and physical features of the Park and estimate the number of cougars that could potentially exist there, (3) evaluate the prey base to determine whether it is sufficient to support the estimated number of cougars, and (4) compare characteristics of the Park to other areas that currently support cougars or have been proposed as possible relocation sites.

My analysis of the Park and comparisons with other areas should help to determine the feasibility of the Park to support a cougar population. The conclusions drawn will be helpful not only in the debate regarding whether cougars should be reintroduced into the Park but also in discussions about other suitable reintroduction areas in the eastern USA. The analytical methods presented here could also be applied to the conservation of other large mammalian carnivores.

\section{Study area}

Adirondack State Park is located in northern New York and was established by legislative decree in 1885 . Within the designated area c. $45 \%$ of the land $\left(\right.$ c. $\left.11,000 \mathrm{~km}^{2}\right)$ is state owned (Fig. 1a). The rest of the land is a mixture of large private forested areas, hamlets and towns, and individual houses/buildings located primarily along the roads. The human population density in the Park is $5.3 \mathrm{~km}^{-2}$, varying from 1.2 persons $\mathrm{km}^{-2}$ in Hamilton County to 12.7 persons $\mathrm{km}^{-2}$ in Fulton County (Table 1 ). The total road density is estimated to be $0.59 \mathrm{~km} \mathrm{~km}^{-2}$ (for calculations see Methods). An estimated 7-10 million people visit the Park annually but the areas visited are distributed unevenly, with most people visiting popular areas such as Lake Placid. Although there are several paved high-traffic roads through the Park, including an interstate section, $88.8 \%$ of the roads are low traffic or unpaved (Fig. 1b).

Vegetation cover is primarily second-growth deciduous and evergreen forest. The dominant deciduous trees are sugar maple Acer saccharum, American beech Fagus grandifolia and yellow birch Betula allaghaniensis (Hurst $\&$ Porter, 2008). The dominant evergreen species include red spruce Picea rubens, black spruce Picea mariana and eastern hemlock Tsuga canadensis (Glennon \& Porter, 2007). Approximately 5.7\% of the Park surface is water. The predominant mammal species are white-tailed deer Odocoileus virginianus, moose Alces alces, coyote Canis latrans, bobcat Lynx rufus, raccoon Procyon lotor and snowshoe hare Lepus americanus.

\section{Methods}

\section{Delineating suitable areas}

To estimate the amount of habitat potentially available to cougars in Adirondack State Park I identified various features where cougars could not or should not live, such as roads, towns and rivers. I estimated the area associated with each feature, as explained below, and subtracted those areas from the total area of the Park.

A main assumption of the earlier analysis was that cougars needed wilderness or wild areas with low human and road densities to survive (Brocke, 1981). Based on current data for cougars living in areas with human and road densities equal to or higher than those in the Park (Dickson et al., 2005; Beier et al., 2010; Kertson, 2010; Maletzke, 2010; Stoner, 2011), I relaxed this assumption substantially. Data indicate that cougars are reluctant to cross paved roads but not dirt roads (Dickson et al., 2005). Accordingly, I assumed that the presence of dirt roads would not affect cougars directly and so did not exclude them from my calculations of areas suitable for cougars. To exclude paved roads, I buffered each road by $200 \mathrm{~m}$ on each side and subtracted this area from the total area of the Park. I calculated the density $\left(\mathrm{km} \mathrm{km}^{-2}\right)$ of paved and dirt roads of different units (e.g. counties, public land) of the Park for comparison with other areas. I obtained the length of paved and dirt roads in the Park and its various political subunits from the United States Geological Survey National Map Seamless Server (2002) shapefiles. Road density for each type of road (e.g. paved or dirt) was defined as the sum of all road lengths of that type within a unit of interest divided by that unit's area. 
(a)

State owned

Managed lands

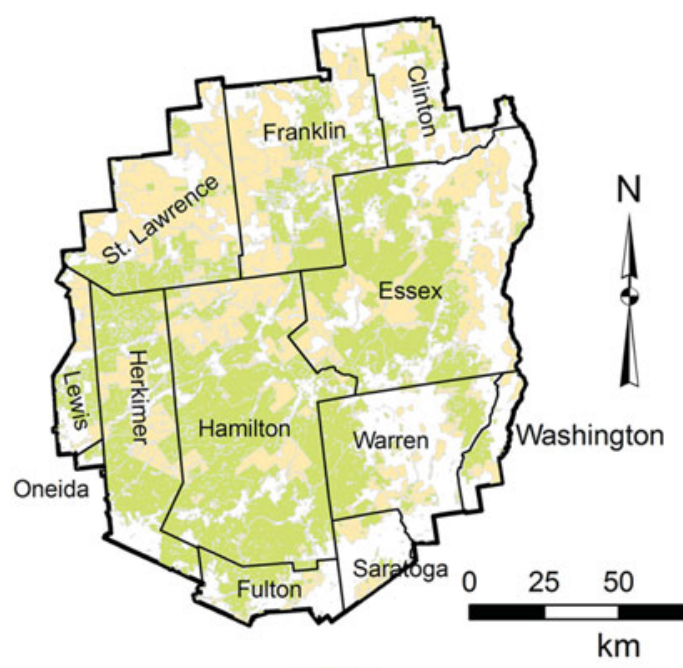

(c)

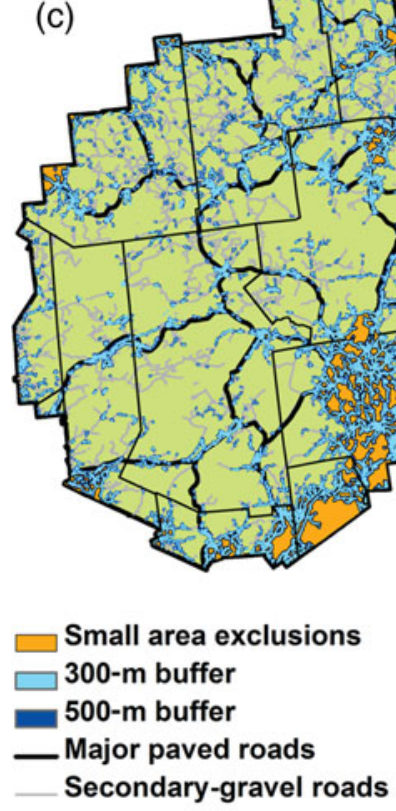

(b)

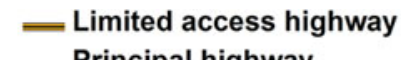

_Principal highway

+ Other through highway

_ Dirt roads

00

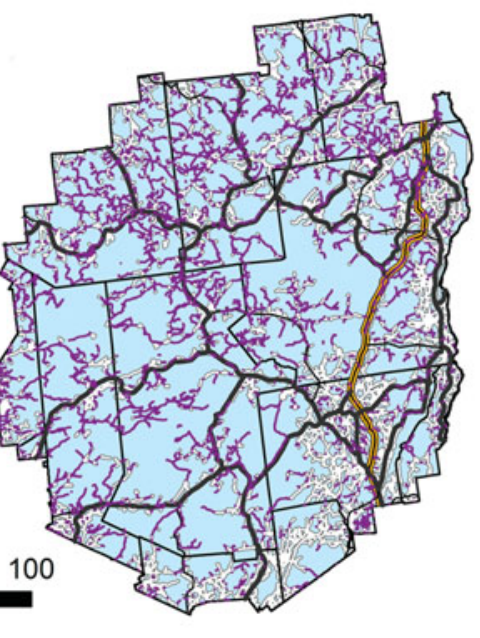

(d)

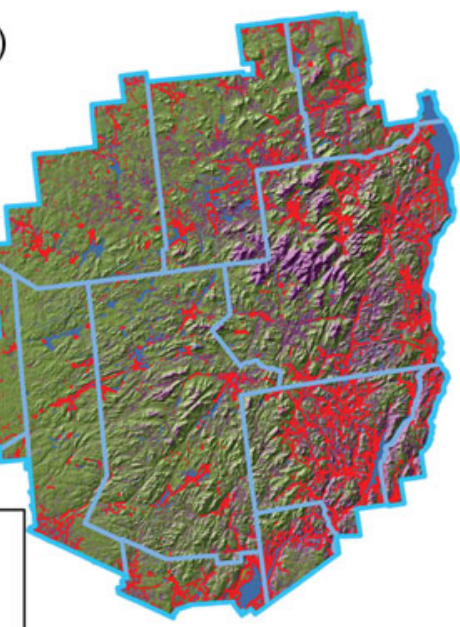

300-m buffer

Open water

Deciduous forest

Evergreen forest

Mixed forest

Woody wetlands

FIG. 1 (a) Outline of Adirondack State Park, indicating the extent of state-owned land and resource management lands; county boundaries are also indicated. (b) Distribution of the various types of roads in the Park; the main roads are paved and carry most of the Park's traffic. (c) Distribution of lands excluded from possible cougar use assuming 300- and 500-m buffers around buildings in the Park. (d) Vegetation composition of the land available for use by cougars; the $300-\mathrm{m}$ buffer is included as a reference to where towns and buildings are located. (e) Location of Adirondack State Park in the state of New York in the north-eastern United States.

Cougars are known to live near, and often come within sight of, houses in rural areas and enter suburban areas on the edge of towns and cities (Beier \& Barrett, 1993; Beier et al., 2010; Kertson, 2010; Maletzke, 2010; Stoner, 2011). However, normally they do not spend much time near houses or buildings and human tolerance for such incursions is relatively low. Consequently, I encompassed each town and hamlet with a circle of radius
1,000 m. Beyond these circles I buffered all houses and buildings with two levels or zones of intolerance, using circles of radius 300 and $500 \mathrm{~m}$. The minimum buffer width was chosen based on the premise that, in forested habitat, cougars could pass within $300 \mathrm{~m}$ of an occupied building without detection. The second width was selected based on cougars' low use of areas $<500 \mathrm{~m}$ from human structures (Beier et al., 2010; Kertson, 2010; Maletzke, 2010). 
TABLE 1 Area of, and density of, people, buildings and roads in Adirondack State Park (Fig. 1) and the various political units within its boundaries.

\begin{tabular}{lcccc}
\hline & Area ${ }^{1}\left(\mathrm{~km}^{2}\right)$ & $\begin{array}{l}\text { Human } \\
\text { density }\left(\mathrm{km}^{-2}\right)\end{array}$ & $\begin{array}{l}\text { Building } \\
\text { density }\left(\mathrm{km}^{-2}\right)\end{array}$ & $\begin{array}{l}\text { Road density } \\
\left.(\mathrm{km} \mathrm{km})^{-2}\right)\end{array}$ \\
\hline Adirondack Park & 24,700 & 5.3 & 2.1 & $0.52 / 0.07 / 0.006$ \\
Clinton County & 1,332 & 11.8 & 2.8 & $0.81 / 0.08$ \\
Essex County & 4,954 & 7.8 & 2.3 & $0.58 / 0.11 / 0.02$ \\
Franklin County & 2,970 & 5.3 & 1.9 & $0.55 / 0.09$ \\
Fulton County & 822 & 12.7 & 6.9 & $0.77 / 0.10$ \\
Hamilton County & 4,661 & 1.2 & 1.1 & $0.31 / 0.06$ \\
Herkimer County & 2,243 & 1.6 & 1.3 & $0.41 / 0.03$ \\
Lewis County & 664 & 1.4 & 8.4 & $0.67 / 0.00$ \\
Oneida County & 67 & 5.1 & 5.1 & $0.82 / 0.15$ \\
Saratoga County & 610 & 12.4 & 0.9 & $0.73 / 0.06$ \\
St Lawrence County & 2,526 & 1.4 & 3.8 & $0.50 / 0.06$ \\
Warren County & 2,253 & 10.9 & 3.4 & $0.80 / 0.15 / 0.02$ \\
Washington County & 433 & 7.6 & 0.05 & $0.74 / 0.10$ \\
State land & 11,100 & $?^{3}$ & 0.82 & $0.16 / 0.04$ \\
Managed land & 6,500 & & & $0.54 / 0.04$ \\
\hline
\end{tabular}

${ }^{1}$ Area of the counties within Park boundaries. All areas are approximate.

${ }^{2}$ Unpaved/paved/high-speed roadways. The only high-speed highway (length $144 \mathrm{~km}$ ) is in Essex and Warren Counties.

${ }^{3}$ There were no data available to estimate human density for state or managed lands

To exclude these areas of human use I digitized town and house locations from county raster images for 2009 available from the United States Department of Agriculture (USDA) Geospatial Data Gateway (2009). The image resolution was $60 \mathrm{~cm}$ and within ArcMap v. 9.3 (ESRI, Redlands, USA) individual buildings were clearly visible. The images were from early spring when deciduous trees lacked leaves, facilitating detection of buildings. Buildings and towns were buffered with the ArcMap buffering tool. I could not distinguish between permanent and seasonal use or between residential and business buildings.

Once towns and buildings were buffered I overlaid the two sizes of buffer layers on the outline of the Park and then subtracted the total buffered areas from the total area of the Park. I obtained a layer for lakes and rivers from a shapefile available from the Shared Adirondack State Park Geographic Information CD-ROM (2001) and, as with towns and buildings, I subtracted these features from the overall surface of the Park. The final map provides estimates of the maximum areas that cougars could use without coming into contact with human habitation at the two buffer distances of 300 and $500 \mathrm{~m}$. I used this map to calculate possible maximum population sizes of cougars in the Park. Using data from NLCD (2001), obtained through the USDA Geospatial Data Gateway, I then overlaid the final map of usable areas on the NLCD habitat and topographic layers to determine the characteristics of the areas available to cougars.

Because little was known of how cougars used the region historically Brocke (1981) assumed that in the summer cougars could use all of the area designated to be highly suitable. In a similar manner I assumed that in the summer cougars could use all possible habitat in these areas. Thus I used the size of the maximum areas cougars could use in the summer under the two buffer sizes when calculating the size of the cougar population in the Park.

\section{Calculating potential numbers of cougars}

To estimate potential ranges of adult cougar population sizes I multiplied the two maximum areas, based on the 300and 500-m buffers, by the densities of 1.0 and 2.0 resident cougars per $100 \mathrm{~km}^{2}$ to represent low and high cougar densities respectively (Logan \& Sweanor, 2001; Laundré et al., 2007). These calculations provided the range of population size possible in the Park under each of the two buffer size scenarios.

Brocke (1981) reported white-tailed deer densities in the Park of 3.3-5.6 $\mathrm{km}^{-2}$, which are similar to the 4.9-6.8 deer $\mathrm{km}^{-2}$ reported for the area by Mathews \& Porter (1993). How these densities were estimated is not explained and so, to provide a conservative estimate, I used Brocke's densities in my calculations. I multiplied his minimum and maximum densities by the maximum areas to obtain a range of two possible white-tailed deer population sizes for each area. To estimate the number of fawns born each year for the two maximum areas I used a 1: 2.6 buck : doe ratio (Mathews \& Porter, 1993) to calculate the number of does. I then multiplied the number of does by a mean 0.80 pregnancy rate and the resulting number by a mean birth rate of 1.2 fawns per doe (DelGiudice et al., 2007) to give estimates of 
the number of fawns born annually for the two population sizes per maximum area.

To estimate the per-capita predation rates (number of deer killed per cougar-year) for cougars I used data from two recent studies to represent minimum and maximum per-capita predation rates of 30 (Laundré, 2008) and 40 deer per cougar-year (Knopff et al., 2010). For each maximum area I multiplied the two adult cougar population estimates by these two per-capita predation rates to obtain a total of four estimates of the total number of deer killed per year. Cougar ungulate prey includes $43 \%$ young of the year (Knopff et al., 2010). Thus I multiplied the four estimates of total deer killed per year by 0.43 and 0.57 to estimate the total young of the year and adult animals killed respectively. For young of the year and adults separately I divided the four mortality estimates of each by the respective total number of fawns and adult deer for the two population estimates. This provided eight estimates each of cougarspecific mortality rates for young of the year and adult deer for different combinations of deer (two) and cougar densities (two) and per-capita predation rates (two) separately for each of the two maximum areas.

I used these mortality rates for adults and fawns to evaluate the potential impact cougars could have on deer in the Park. Although cougars elsewhere are known to prey on other species that are found in the Park, such as moose or snowshoe hares (Knopff et al., 2010), this is mostly incidental and I did not include such predation in my calculations.

\section{Results}

The density of buildings beyond the municipal areas for the whole Adirondack State Park was $2.1 \mathrm{~km}^{-2}$. Within counties building densities were $0.9-8.4 \mathrm{~km}^{-2}$ (Table 1). Oneida County had the highest density of buildings but the smallest amount of land within the Park $\left(67 \mathrm{~km}^{2}\right)$. The density of buildings within state-owned land was 0.05 buildings $\mathrm{km}^{-2}$. Within resource management lands, used primarily for timber production, the density of houses was $0.82 \mathrm{~km}^{-2}$. In the remaining land-use classes, except for towns and hamlets, the density of buildings was $8.3 \mathrm{~km}^{-2}$. The total road density in the Park is $0.59 \mathrm{~km} \mathrm{~km}^{-2}$ and road densities vary among the counties (Table 1; Fig. 1b). The paved road density in the Park is $0.07 \mathrm{~km} \mathrm{~km}^{-2}$.

There were $20,350 \mathrm{~km}^{2}$ of land beyond the $300-\mathrm{m}$ buffer and $17,658 \mathrm{~km}^{2}$ beyond the 500-m buffer (Fig. 1c, Table 2). Total road density for the 300- and 500-m buffers was 0.33 and $0.24 \mathrm{~km} \mathrm{~km}^{-1}$, respectively. For both areas road densities consisted mainly of unpaved roads (Table 2). Building density was, by definition, 0.0 and because of that permanent human use of these areas was also considered to be o.o. The two defined areas included water bodies, paved roads and small $\left(<200 \mathrm{~km}^{2}\right)$ isolated parcels that cougars
TABle 2 Total maximum areas within Adirondack State Park (Fig. 1) after the removal of lands within 300-m and 500-m buffers around houses and the 1,000-m buffer around towns, the amount of usable cougar Puma concolor habitat (which is the total maximum area minus the amount of area occupied by lakes, rivers, and roads plus the small, $<200 \mathrm{~km}^{2}$, areas surrounded by the buffered towns and houses), and the density of unpaved and paved roads and high speed highway.

\begin{tabular}{lll}
\hline & $300-\mathrm{m}$ buffer & 500 -m buffer \\
\hline Total maximum area $\left(\mathrm{km}^{2}\right)$ & 20,350 & 17,658 \\
Usable cougar habitat & 17,093 & 15,287 \\
Road density & & \\
Unpaved roads & 0.30 & 0.22 \\
Paved roads & 0.03 & 0.02 \\
High speed highway & 0.0 & 0.0 \\
\hline
\end{tabular}

could not use. These areas were subtracted from the totals to give estimates of the amount of usable cougar habitat (Table 2).

The maximum areas include the mountainous regions towards the centre of the Park and the lower flatter lands to the east (Fig. 1C). The habitat throughout the maximum areas is a mixture of evergreen and deciduous forest, with evergreen forests dominating the more mountainous areas and deciduous forest with wooded wetlands dominating the lower elevations to the west (Fig. 1c). Open grass and shrub habitat accounts for c. $14 \%$ of the two maximum areas.

\section{Estimation of potential cougar numbers}

In the $17,093 \mathrm{~km}^{2}$ of the $300-\mathrm{m}$ buffer the estimated number of cougars at densities of 1.0 and 2.0 per $100 \mathrm{~km}^{2}$ was 171 and 342 , respectively, the estimated number of deer at densities of 3.3 and $5.6 \mathrm{~km}^{-2}$ was 56,407 and 95,721 , respectively, and fawn production of these deer populations was estimated to be 39,096 and 66,346 per year, respectively (Table 3). At the two per-capita predation rates the number of adult deer killed would be 2,923-7,794 and the number of fawns killed would be 2,204-5,880 (Table 3). Corresponding estimates for the 500-m buffer are also given in Table 3 . Because I used the same density estimates of cougars and deer for both buffer sizes the proportional relationships among cougar and deer numbers and the number of deer killed, and thus mortality rates, was the same for both scenarios (Table 4). Cougar-specific mortality rates would range from 3.1-13.8\% for adult deer and $3.3-15.0 \%$ for fawns (Table 4).

\section{Comparisons with other areas}

The Black Hills of South Dakota are similar to Adirondack State Park in that much of the area is mountainous, with some peaks in both areas reaching c. 1,200 m. Both areas are heavily forested, are a mixture of public and private land and 
TABLE 3 Calculations of the potential number of cougars, adult deer, and deer fawns born annually, at low and high densities, for the maximum available areas after subtraction of 300- and 500-m buffers around houses and buildings (see text for details), and similarly deer and fawn mortality at low and high rates of predation by cougars, in Adirondack State Park (Fig. 1).

\begin{tabular}{|c|c|c|c|c|}
\hline & 300-m buffer & & 500-m buffer & \\
\hline \multicolumn{5}{|l|}{ Number of cougars } \\
\hline Low density $\left(1\right.$ per $\left.100 \mathrm{~km}^{2}\right)$ & 171 & & 152 & \\
\hline High density $\left(2\right.$ per $\left.100 \mathrm{~km}^{2}\right)$ & 342 & & 304 & \\
\hline \multicolumn{5}{|l|}{ Number of adut deer } \\
\hline Low density $\left(3.3 \mathrm{~km}^{-2}\right)$ & 56,407 & & 50,447 & \\
\hline High density $\left(5.6 \mathrm{~km}^{-2}\right)$ & 95,721 & & 85,607 & \\
\hline \multicolumn{5}{|l|}{ Number of fawns born annually ${ }^{*}$} \\
\hline Low deer density $\left(3.3 \mathrm{~km}^{-2}\right)$ & 39,096 & & 34,966 & \\
\hline \multirow[t]{2}{*}{ High deer density $\left(5.6 \mathrm{~km}^{-2}\right)$} & 66,346 & & 59,336 & \\
\hline & $\begin{array}{l}\text { Low cougar } \\
\text { density }\end{array}$ & $\begin{array}{l}\text { High cougar } \\
\text { density }\end{array}$ & $\begin{array}{l}\text { Low cougar } \\
\text { density }\end{array}$ & $\begin{array}{l}\text { High cougar } \\
\text { density }\end{array}$ \\
\hline \multicolumn{5}{|l|}{ Adult deer killed } \\
\hline Low predation rate (30 deer per cougar-year) & 2,923 & 5,846 & 2,614 & 5,228 \\
\hline High predation rate (40 deer per cougar-year) & 3,897 & 7,794 & 3,485 & 6,971 \\
\hline \multicolumn{5}{|l|}{ Fawns killed } \\
\hline Low predation rate (30 deer per cougar-year) & 2,204 & 4,410 & 1,972 & 3,944 \\
\hline High predation rate ( 40 deer per cougar-year) & 2,940 & 5,880 & 2,629 & 5,228 \\
\hline
\end{tabular}

${ }^{\star}$ Based on a doe : buck ratio of $2.6: 1$, pregnancy rate of 0.80 and a birth rate of 1.2 fawns per female

TABLE 4 Calculated mortality rates (\%) of adult deer and fawns at low and high cougar and deer densities and low and high cougar predation rates in Adirondack State Park (Fig. 1). Because I used the same cougar and deer densities, the number of cougars, deer, and deer killed changed proportionally between the $300-\mathrm{m}$ and $500-\mathrm{m}$ buffer scenarios, resulting in equal mortality rates for the two scenarios.

\begin{tabular}{|c|c|c|c|c|}
\hline & \multicolumn{2}{|c|}{ Low cougar density ( 1 per $\left.100 \mathrm{~km}^{2}\right)$} & \multicolumn{2}{|c|}{ High cougar density (2 per $\left.100 \mathrm{~km}^{2}\right)$} \\
\hline & $\begin{array}{l}\text { Low deer density } \\
\left(3.3 \mathrm{~km}^{-2}\right)\end{array}$ & $\begin{array}{l}\text { High deer density } \\
\left(5.6 \mathrm{~km}^{-2}\right)\end{array}$ & $\begin{array}{l}\text { Low deer density } \\
\left(3.3 \mathrm{~km}^{-2}\right)\end{array}$ & $\begin{array}{l}\text { High deer density } \\
\left(5.6 \mathrm{~km}^{-2}\right)\end{array}$ \\
\hline \multicolumn{5}{|l|}{ Adult deer } \\
\hline Low predation rate (30 deer per cougar-year) & 5.2 & 3.1 & 10.4 & 6.1 \\
\hline High predation rate ( 40 deer per cougar-year) & 6.9 & 4.1 & 13.8 & 8.1 \\
\hline \multicolumn{5}{|l|}{ Fawns } \\
\hline Low predation rate (30 deer per cougar-year) & 5.6 & 3.3 & 11.3 & 6.6 \\
\hline High predation rate (40 deer per cougar-year) & 7.5 & 4.4 & 15.0 & 8.9 \\
\hline
\end{tabular}

have similar human and deer densities (Table 5). However, the Black Hills have a higher road density (Rumble et al., 2005) and cover a much smaller area than Adirondack State Park (Table 5). Cougars recolonized the Black Hills late in the 2oth century and currently there is an estimated population of 130-140 adult cougars (SDGFP, 2010), which is a density of $1.5^{-1.7}$ cougars per $100 \mathrm{~km}^{2}$ (my calculations). Collisions with vehicles account for the death of c. 4.5 cougars per year, mostly young dispersing males, but this level of mortality does not seem to affect the population. Based on the Black Hills example, Adirondack State Park would seem to be suitable for occupation by cougars.

The second comparison is with southern Florida, where the only remnant southern panther Puma concolor coryii population occurs in an area of c. $12,600 \mathrm{~km}^{2}$ (Land et al., 2008). Like Adirondack State Park, the southern Florida area is a mixture of public (77\%) and private land (23\%) and has similar road and deer densities (Table 5) but it is smaller. The panther population of this area is estimated to be 100-120 adults producing at least 20-40 kittens annually. This panther population is surrounded by high levels of human development, including the Miami-Fort Lauderdale metropolitan area. Because of the high annual panther production and the closed nature of the population an estimated 14-20 panthers, mostly young dispersers, are killed annually on highways (Florida Fish and Wildlife Conservation Commission, 2011).

The third comparison involves 11 sites in south-eastern USA that have been evaluated as potential reintroduction sites for the Florida panther (Thatcher et al., 2003, 2006). Of these 11 sites three were ranked as having high and six as moderate potential for reintroduction releases. The effective 
TABLE 5 Comparison of Adirondack State Park with areas with established cougar habitat (Black Hills and southern Florida) and predicted suitable cougar habitat (southern Georgia and western Arkansas).

\begin{tabular}{|c|c|c|c|c|c|}
\hline & $\begin{array}{l}\text { Area } \\
\left(\mathrm{km}^{2}\right)\end{array}$ & $\begin{array}{l}\text { Human } \\
\text { density } \\
\left(\mathrm{km}^{-2}\right)\end{array}$ & $\begin{array}{l}\text { Road } \\
\text { density }^{1} \\
\left(\mathrm{~km} \mathrm{~km}^{-2}\right)\end{array}$ & $\begin{array}{l}\text { Prey } \\
\text { density } \\
\left(\mathrm{km}^{-2}\right)\end{array}$ & $\begin{array}{l}\text { Cougar } \\
\text { density } \\
\left(100 \mathrm{~km}^{-2}\right)\end{array}$ \\
\hline Adirondack State Park & 24,000 & 5.3 & $0.52 / 0.07$ & 5.6 & \\
\hline Black Hills, South Dakota & 8,400 & 5.1 & $3.2^{2}$ & $5.4^{3}$ & $1.5-1.7$ \\
\hline Southern Florida & 12,600 & 3.5 & $0.33 / 0.038^{4}$ & $5.8^{4}$ & $0.79-1$ \\
\hline $\begin{array}{l}\text { Okefenokee National Wildlife Refuge, southern } \\
\text { Georgia }^{4}\end{array}$ & 4,112 & 4.0 & $0.9 / 0.06$ & 5.8 & \\
\hline Ozark National Forest, western Arkansas ${ }^{5}$ & 5,270 & 5.4 & $1.1 / 0.06$ & 5.8 & \\
\hline Felsenthal National Wildlife Refuge, western Arkansas ${ }^{5}$ & 8,161 & 9.6 & $1.2 / 0.07$ & 11.7 & \\
\hline
\end{tabular}

${ }^{1}$ Unpaved/paved roadways

${ }^{2}$ Rumble et al. (2005)

${ }^{3}$ Calculated from Terrall et al. (2005)

${ }^{4}$ Thatcher et al. (2003)

${ }^{5}$ Estimates from three high-potential sites for Florida panther reintroduction (Thatcher et al., 2003, 2006)

sizes of the habitat areas (similar to the maximum areas used in this study) for the three high potential sites are all substantially smaller than that of Adirondack State Park (Table 5). The total road densities are all higher and human population densities are $4.0-9.6 \mathrm{~km}^{-2}$ in the three sites compared with $5.3 \mathrm{~km}^{-2}$ in Adirondack State Park (Table 5). The deer densities for two of the sites are similar to those in the Park (Table 5).

\section{Discussion}

Brocke's (1981) report on the feasibility of cougars living in Adirondack State Park was based on the knowledge of cougar biology at the time. One overriding assumption was that cougars are animals of wild areas. It is likely that this assumption arose because it was only in the more remote areas of the west where cougars were able to survive persecution by humans, which continued up to the 1970 s. Based on this assumption Brocke identified the most remote regions in the Park, a relatively small area of $7,500 \mathrm{~km}^{2}$, as suitable for cougars. Most western states now have wellcontrolled hunting seasons for the cougar and studies have demonstrated that the original assumption about where cougars can live can be relaxed (Beier \& Barrett, 1993; Laundré, 2008; Thompson, 2009; Beier et al., 2010; Kertson, 2010; Maletzke, 2010; Stoner, 2011). Based on these studies I redefined the criteria for suitable cougar habitat.

Under these redefined criteria the estimated area that cougars could inhabit increased to $16,000-19,000 \mathrm{~km}^{2}$. Figs 1a \& c show that most of this area is state-owned land and private land managed for forest products. Although there are 7-10 million visitors to the Park annually the total number of visitors per $\mathrm{km}^{2}(283-404)$ is similar to that of Yellowstone Park (2.2 million visitors; 245 persons $\mathrm{km}^{-2}$ ). As in Yellowstone the distribution of visitors to Adirondack
State Park is concentrated in high-interest areas, leaving the state-owned and privately managed lands relatively undisturbed. Although there is some danger of cougars being killed on paved roads in the Park, the low density of these highways suggests that road-related mortality would be low. Within most of the areas where cougars could roam they could therefore move across large tracts of land, encounter few people and only have to cross dirt roads.

Both my study and that of Brocke (1981) indicate there would be sufficient deer for the cougar population that it is estimated Adirondack State Park could support. Both studies conclude that the impact of cougars on deer numbers in the Park would be minimal. Regardless of the number of cougars, only under the worst-case scenario of high cougar but low deer density would cougars take $>10 \%$ of the adult deer population. Even with this scenario fawn production would still outpace deer mortality rates of $15 \%$ from predation by cougars. Thus there is no indication that cougars would adversely affect deer populations in the Park.

A comparison of Adirondack State Park with other areas supports the conclusion that the Park could support a population of 150-350 cougars. These animals would be able to move freely about the Park without substantial contact with humans. There would be some mortality from roadrelated causes and removal of animals either legally or illegally but the population would probably be selfsustaining. Other areas in the north-eastern USA provide similar habitat and a population in Adirondack could potentially expand beyond the Park to establish populations across a broad geographical range, adding to the long-term viability of the species.

In conclusion, the analyses presented here support the proposition that Adirondack State Park has sufficient habitat and food resources to support a viable cougar population. These analyses also provide a method to evaluate the adequacy of an area for large mammalian 
carnivores. Although estimating the amount of potential habitat available is important, the estimation of the potential population size that could be supported and the adequacy of the prey base are of particular importance. By use of upto-date information on the biology and ecology of the species of interest, especially regarding habitat and food requirements, conclusions can be drawn about the feasibility of reintroducing a carnivore species into a particular area.

Although the results of such an analysis for a large mammalian carnivore can be favourable for reintroduction it does not necessarily follow that the social environment is suitable. Common social issues raised about the return of cougars and other large carnivores include concerns (1) from sportsmen (e.g. whether the return of a carnivore will negatively affect hunting opportunities for ungulate prey), (2) from livestock owners regarding depredation by large carnivores, and (3) about public safety (e.g. what risks these species pose to human life). For the successful reintroduction of cougars or any large carnivore each of these concerns has to be addressed. In the case of cougars the high level of public concern regarding these issues is not supported by scientific data. Most studies have demonstrated that cougars do not have significant impacts on ungulate populations (Ballard et al., 2001; Laundré et al., 2006), are not a significant threat to livestock (Mazzolli et al., 2002; Bueno-Cabrera et al., 2005; Palmer et al., 2010), and that the threat to humans from cougars is relatively low (Beier, 1991). In addition, established protocols to deal with situations involving cougars have been developed (Cougar Management Guidelines Working Group, 2005). If we address these issues in light of existing data rather than emotional rhetoric, there is a high probability that cougars could be successfully reintroduced to Adirondack State Park and other suitable areas in the eastern USA. What is now required is the will to bring them back.

\section{Acknowledgements}

This study was undertaken while the author was an adjunct professor at the State University of New York at Oswego (SUNY Oswego), USA. I thank SUNY Oswego for the logistic and financial support to conduct the geographical information system analyses. I also thank the many dedicated cougar biologists who over the years have provided the data on the behaviour and ecology of cougars that have made this analysis possible.

\section{References}

Ballard, W.B., Lutz, D., Keegan, T.W., Carpenter, L.H. \& DEVos, Jr, J.C. (2001) Deer-predator relationships: a review of recent North American studies with emphasis on mule and black-tailed deer. Wildlife Society Bulletin, 29, 99-115.

BeIER, P. (1991) Cougar attacks on humans in the United States and Canada. Wildlife Society Bulletin, 19, 403-412.

Beier, P. \& Barrett, R.H. (1993) The Cougar in the Santa Ana Mountain Range, California. Final Report, Orange County Cooperative Mountain Lion Study, Santa Ana, USA.

Beier, P., Riley, S.P.D. \& Sauvajot, R.M. (2010) Mountain lions (Puma concolor). In Urban Carnivores: Ecology, Conflict, and Conservation (eds S.D. Gehrt, S.P.D. Riley \& B.L. Cypher), pp. 141-156. The Johns Hopkins University Press, Baltimore, USA.

Bolgiano, C. \& Roberts, J. (2005) The Eastern Cougar: Historic Accounts, Scientific Investigations, New Evidence. Stackpole Books, Mechanicsburg, USA.

BRocke, R.H. (1981) Reintroduction of the Cougar (Felis concolor) in Adirondack Park: A Problem Analysis and Recommendations. Final Report Federal Aid Project E-1-9, New York State Department of Environmental Conservation, New York, USA.

Bueno-Cabrera, A., Hernández-Garcia, L., Laundré, J., Contreras-Hernández, A. \& Shaw, H. (2005) Cougar impact on livestock ranches in the Santa Elena Canyon, Chihuahua, Mexico. Mountain Lion Workshop, 8, 141-149.

Caso, A., Lopez-Gonzalez, C., Payan, E., Eizirik, E., De Oliveira, T., Leite-Pitman, R. et al. (2008) Puma concolor. In IUCN Red List of Threatened Species v. 2012.1. Http://www. iucnredlist.org [accessed 12 September 2012].

Cougar Management Guidelines Working Group (2005) Cougar Management Guidelines, 1st edition. Wildfutures, Brainbridge Island, USA.

DAwn, D. (2002) Management of cougars (Puma concolor) in the western United States. MSc thesis, San Jose State University, San Jose, USA.

DelGiudice, G.D., Lenarz, M.S. \& Carstensen Powell, M. (2007) Age-specific fertility and fecundity in northern free-ranging white-tailed deer: evidence for reproductive senescence? Journal of Mammalogy, 88, 427-435.

Dickson, B.G., Jenness, J.S. \& Beier, P. (2005) Influence of vegetation, topography, and roads on cougar movement in southern California. Journal of Wildlife Management, 69, 264-276.

Florida Fish and Wildlife Conservation Commission (2011) Annual Report on the Research and Management of Florida Panthers: 2010-2011. Http://www.floridapanthernet.org/index.php/ reports/ [accessed 13 November 2012].

Gittleman, J.L. \& Gompper, M.E. (2001) The risk of extinction -what you don't know will hurt you. Science, 291, 997-999.

Glennon, M.J. \& Porter, W.F. (2007) Impacts of land-use management on small mammals in the Adirondack Park, New York. Northeastern Naturalist, 14, 323-342.

Hornocker, M.B. (1970) An analysis of mountain lion predation upon mule deer and elk in the Idaho Primitive Area. Wildlife Monograph, 21, 1-39.

Hornocker, M.B. \& Negri, S. (eds) (2010) Cougar Ecology and Conservation. University of Chicago Press, Chicago, USA.

Hurst, J.E. \& Porter, W.F. (2008) Evaluation of shifts in white-tailed deer winter yards in the Adirondack region of New York. Journal of Wildlife Management, 72, 367-375.

Kertson, B.M. (2010) Cougar ecology, behavior, and interactions with people in a wildland-urban environment in western Washington. PhD dissertation, University of Washington, Seattle, USA.

Knopff, K.H., Knopff, A.A., Kortello, A. \& Boyce, M.S. (2010) Cougar kill rate and prey composition in a multiprey system. Journal of Wildife Management, 74, 1435-1447. 
Land, E.D., Shindle, D.B., Kawula, R.J., Benson, J.F., Lotz, M.A. \& ONORATO, D.P. (2008) Florida panther habitat selection analysis of concurrent GPS and VHF telemetry data. Journal of Wildlife Management, 72, 633-639.

LAUndRÉ, J.W. (2008) Summer predation rates on ungulate prey by a large keystone predator: how many ungulates does a large predator kill? Journal of Zoology, 275, 341-348.

Laundré, J.W., Hernández, L. \& Clark, S.G. (2006) Impact of puma predation on the decline and recovery of a mule deer population in southeastern Idaho. Canadian Journal of Zoology, 84, $1555-1565$.

Laundré, J.W., Hernández, L. \& Clark, S.G. (2007) Numerical and demographic responses of pumas to changes in prey abundance: testing current predictions. Journal of Wildlife Management, 71, $345-355$.

Lindzey, F.G., Ackerman, B.B., Barnhurst, D. \& Hemker, T.P. (1988) Survival rates of mountain lions in southern Utah. Journal of Wildlife Management, 52, 664-667.

Logan, K.A. \& Sweanor, L.L. (2001) Desert Puma: Evolutionary Ecology and Conservation of an Enduring Carnivore. Island Press, Washington, DC, USA.

MaletzKe, B.T. (2010) Effects of anthropogenic disturbance on landscape ecology of cougars. $\mathrm{PhD}$ dissertation, Washington State University, Pullman, USA.

Mathews, N.E. \& Porter, W.F. (1993) Effect of social structure on genetic structure of free-ranging white-tailed deer in the Adirondack mountains. Journal of Mammalogy, 74, 33-43.

Mazzolli, M., Graipel, M.E. \& Dunstone, N. (2002) Mountain lion depredation in southern Brazil. Biological Conservation, 105, 43-51.

Nilsen, E.B., Milner-Gulland, E.J., Schofield, L., Mysterud, A., Stenseth, N.C. \& Coulson, T. (2007) Wolf reintroduction to Scotland: public attitudes and consequences for red deer management. Proceedings of the Royal Society of Biological Sciences, 274, 995-1002.

Palmer, B.C., Conover, M.R. \& Frey, S.N. (2010) Replication of a 1970 study on domestic sheep losses to predators on Utah's summer rangelands. Rangeland Ecology and Management, 63, 689-695.

Pyare, S., Cain, S., Moody, D., Schwartz, C. \& Berger, J. (2004) Carnivore re-colonization: reality, possibility and a non-equilibrium century for grizzly bears in the southern Yellowstone ecosystem. Animal Conservation, 7, 71-77.

Rumble, M.A., Kenkobi, L. \& Gamo, R.S. (2005) Elk response to humans in a densely roaded area. Intermountain Journal of Science, $11,10-24$.
SDGFP (2010) South Dakota Mountain Lion Management Plan 2010-2015, Version 10-1. South Dakota Department of Game, Fish \& Parks, Pierre, USA.

Seidensticker, J.C. IV, Hornocker, M.G., Wiles, W.V. \& Messick, J.P. (1973) Mountain lion social organization in the Idaho Primitive Area. Wildlife Monographs, 35, 3-60.

Shared Adirondack State Park Geographic Information CD-ROM (2001) Http://www.apa.state.ny.us/gis/shared/index. html [accessed 13 September 2012].

StOneR, D.C. (2011) Ecology and conservation of cougars in the eastern Great Basin: effects of urbanization, habitat fragmentation, and exploitation. $\mathrm{PhD}$ thesis, Utah State University, Logan, USA.

Terrall, D.F., Monteith, K.L., Grovenburg, T.W., Burris, G.M., Hien, B.M., Swanson, C.C. et al. (2005) Population models for white-tailed deer in the Black Hills of South Dakota. Proceedings of the South Dakota Academy of Science, 84, 119-127.

Thatcher, C., van Manen, F.T. \& Clark, J.D. (2003) Habitat Assessment to Identify Potential Sites for Florida Panther Reintroduction in the Southeast. Unpublished Final Report. US Fish and Wildlife Service, Washington, DC, USA.

Thatcher, C.A., Van Manen, F.T. \& Clark, J.D. (2006) Identifying suitable sites for Florida panther reintroduction. Journal of Wildlife Management, 70, 752-763.

Thompson, D.J. (2009) Population demographics of cougars in the Black Hills: survival, dispersal morphometry, genetic structure, and associated interactions with density dependence. $\mathrm{PhD}$ thesis. South Dakota State University, Brookings, USA.

Treves, A. (2009) Hunting for large carnivore conservation. Journal of Applied Ecology, 46, 1350-1356.

United States Department of Agriculture (2009) Geospatial Data Gateway. Http://datagateway.nrcs.usda.gov/GDGHome.aspx [accessed 13 September 2012].

United States Geological Survey (2002) National Map Seamless Server. Http://gisdata.usgs.gov/Website/Seamless/viewer.htm [accessed 13 September 2012].

Young, S.P. \& Goldman, E.A. (1946) The Puma: Mysterious American Cat. Dover Publications, New York, USA.

\section{Biographical sketch}

JOHN LAUNDRÉ's research interests include the ecology, behaviour and conservation of cougars and other large predators. He has studied cougars for more than 20 years in their current range in the western USA and Mexico. He is interested in using this knowledge of cougars to study the possible restoration of cougar populations to their former range in the eastern USA. 